\title{
Upaya Meningkatkan Kemampuan Berbicara Anak Usia Dini Melalui Metode Bercakap-Cakap
}

Tuti Hayati ${ }^{1}$, Heri Hidayat ${ }^{2}$, Nur Ilahiah ${ }^{3}$

Jurusan Pendidikan Islam Anak Usia Dini, UIN Sunan Gunung Djati Bandung e-mail : nurilahiah79@gmail.com

\begin{abstract}
ABSTRAK. Berdasarkan studi pendahuluan melalui kegiatan observasi diperoleh informasi dari guru RA Bustanul Aulad bahwa di kelompok A RA Bustanul Aulad terdapat 4 dari 7 anakyang mengalami hambatan kemampuan berbicara. Hal ini terlihat dari respon anak terhadap pertanyaan sederhana yang disampaikan oleh guru pada saat pembelajaran berlangsung, tidak semua anak mampu menjawab pertanyaan bahkan ada anak yang cenderung diam dan tidak merespon pertanyaan. Tujuan penelitian ini untuk mengetahui: 1) Kemampuan berbicara anak usia dini sebelum diterapkan metode bercakap-cakap di kelompok A RA Bustanul Aulad Permata Biru Cileunyi Bandung; 2) Penerapan metode bercakap-cakap di kelompok A RA Bustanul Aulad Permata Biru Cileunyi Bandung pada setiap siklus; dan 3) Kemampuan berbicara anak usia dini setelah diterapkan metode bercakap-cakap di kelompok A RA Bustanul Aulad Permata Biru Cileunyi Bandung pada setiap siklus. Metode yang digunakan adalah penelitian tindakan kelas dengan pendekatan gabungan dengan menggunakan teknik pengumpulan data berupa observasi dan unjuk kerja.. Hasil penelitian menunjukkan bahwa metode bercakap-cakap mampu meningkatkan kemampuan berbicara anak usia dini. Hal ini terbukti berdasarkan analisis data, bahwa kemampuan berbicara anak sebelum diterapkan metode bercakap-cakap memperoleh nilai rata-rata 40.91 dengan kategori gagal. Selanjutnya, kemampuan berbicara anak setelah diterapkan metode bercakap-cakap pada siklus I diperoleh nilai rata-rata sebesar 51.14 dengan kategori kurang. Sedangkan pada siklus II memperoleh nilai rata-rata sebesar 70.62 dengan kategori baik. Dengan demikian hipotesis yang diajukan diterima, artinya metode bercakapcakap terbukti dapat meningkatkan kemampuan berbicara anak di kelompok A RA Bustanul Aulad Permata Biru Cileunyi Bandung.
\end{abstract}

Kata Kunci : Anak Usia Dini; Kemampuan Berbicara; Metode Bercakap-cakap

ABSTRACT. Based on a preliminary study through observation activities, information was obtained from the teacher RA Bustanul Aulad that in group A RA Bustanul Aulad there were 4 out of 7 children who experienced speech problems. This can be seen from the children's responses to simple questions submitted by the teacher during learning, not all children are able to answer questions, even some children tend to be silent and do not respond to questions. The purpose of this study was to determine: 1) Early childhood speech skills before the method of conversing in group A RA Bustanul Aulad Permata Biru Cileunyi Bandung; 2) Application of the conversation method in group A RA Bustanul Aulad Permata Biru Cileunyi Bandung in each cycle; and 3) Early childhood speaking skills after the method of conversing in group $A R A$ Bustanul Aulad Permata Biru Cileunyi Bandung in each cycle. The method used was classroom action research with a combined approach using data collection techniques in the form of observation and performance. The results showed that the conversation method was able to improve the speaking ability of early childhood. This is proven based on data analysis, that the children's speaking ability before the converse method was applied obtained an average score of 40.91 in the failing 
category. Furthermore, the children's speaking ability after the conversing method was applied in the first cycle obtained an average value of 51.14 in the poor category. Whereas in the second cycle obtained an average value of 70.62 in the good category. Thus the hypothesis proposed is accepted, meaning that the method of conversing is proven to improve the speaking ability of children in group A RA Bustanul Aulad Permata Biru Cileunyi Bandun.

Keyword : Early Childhood; Speech Ability; Conversation Methods

\section{PENDAHULUAN}

Pendidikan Anak Usia Dini secara garis besar diartikan oleh Sutiana sebagai cara berupa tindakan yang dilakukan oleh orang tua dan pendidik dalam proses pendidikan anak dan lingkungan dimana anak dapat mengekplorasikan pengalamannya[1]. Pendidikan anak usia dini secara umum memiliki tujuan untuk mengembangkan seluruh potensi yang dimiliki oleh anak. Menurut Sya'diah bahwa anak usia 2 - 6 tahun memiliki 6 aspek perkembangan yang perlu dicapai meliputi perkembangan fisik motorik, kognitif, sosial emosional, nilai moral agama, seni, dan bahasa[2]. Aspek perkembangan bahasa pada anak usia dini memiliki berbagai macam bentuk, menurut Sutiana terdapat empat macam bentuk perkembangan bahasa pada anak usia dini, diantaranya: menyimak, berbicara, membaca, dan menulis[3].

Berbicara merupakan kemampuan anak yang dapat ditingkatkan melalui berbagai macam metode salah satunya melalui metode bercakap-cakap. selanjutnya Isnaini mengungkapkan bahwa metode bercakap-cakap merupakan interaksi non formal yang bersifat menyenangkan, baik interaksi yang terjadi antara guru dengan anak didik atau antara anak dengan anak[4]. Metode bercakap-cakap ini merupakan salah satu metode yang efektif digunakan dalam proses pendidikan[5]. Adapun manfaat dari metode bercakap-cakap itu sendiri meliputi: mengukur kemampuan anak pada pembendaharaan kata; menambah pembendaharaan kata; memperbaiki kesalahan kata pada anak; mengajarkan penggunaan bahasa yang baik; dan menikmati permainan bahasa[6].

Berdasarkan studi pendahuluan melalui kegiatan observasi terhadap guru RA Bustanul Aulad diketahui bahwa di kelompok A RA Bustanul Aulad terdapat 4 dari 7 anak yang mengalami hambatan perkembangan bahasa dalam kemampuan berbicara. Hal ini terlihat dari respon anak terhadap pertanyaan sederhana yang disampaikan oleh guru pada saat pembelajaran berlangsung, tidak semua anak mampu menjawab pertanyaan dengan benar bahkan ada anak yang tidak mampu menjawab pertanyaan. Hambatan kemampuan berbicara ini disebabkan oleh sedikitnya kosa kata yang dimiliki oleh anak sehingga anak belum mampu menjawab pertanyan sederhana yang di sampaikan oleh guru.Proses pembelajaran di kelompok A RA Bustanul Aulad difokuskan pada pola pembelajaran menggunakan lembar kerja siswa sehingga kurang memberikan kesempatan anak untuk menyampaikan pendapat atau ide gagasan yang menjadikan anak kurang terampil dalam berbicara. Mengingat pentingnya kemampuan berbicara bagi anak usia dini, maka upaya yang diterapkan yaitu dengan cara menciptakan 
suasana belajar yang komunikatif melalui metode yang sesuai dengan tahap perkembangan anak.

Bersumber pada uraian di atas peneliti bermaksud untuk meningkatkan kemampuan berbicara anak di kelompok A RA Bustanul Aulad melalui metode bercakap-cakap. Metode bercakap-cakap merupakan metode yang dapat diterapkan pada anak usia dini serta tepat digunakan untuk meningkatkan kemampuan berbicara anak. Melalui bercakap-cakap menjadikan anak untuk sering berkomunikasi baik dengan guru atau anak lainnya. maka dari itu judul penelitian yang diangkat adalah "Upaya Meningkatkan Kemampuan Berbicara Anak Usia Dini melalui Metode Bercakapcakap (Penelitian Tindakan Kelas di Kelompok A RA Bustanul Aulad Permata Biru Cileunyi Bandung)". selanjutnya penelitian ini bertujuan untuk mengetahui: (1) Kemampuan berbicara anak usia dini sebelum diterapkan metode bercakap-cakap di kelompok A RA Bustanul Aulad Permata Biru Cileunyi Bandung. (2) Penerapan metode bercakap-cakap di kelompok A RA Bustanul Aulad Permata Biru Cileunyi Bandung pada setiap siklus. Dan (3) Kemampuan berbicara anak usia dini setelah diterapkan metode bercakap-cakap di kelompok A RA Bustanul Aulad Permata Biru Cileunyi Bandung pada setiap siklus.

\section{METODE}

Metode penelitian yang digunakan pada penelitian ini menggunakan metode penelitian tindakan kelas. Penulis menggunakan model penelitian dari Kemmis dan McTaggart dalam sukardi, secara garis besar dalam penelitian tindakan kelas model Kemmis dan McTaggart terdapat empat komponen penting yang selalu ada pada setiap siklus yaitu planning (perencanaan), acting (tindakan), observing (observasi) dan reflecting (refleksi)[7]. Keempat komponen tersebut memiliki keterkaitan yang menunjukan sebuah siklus atau disebut juga kegiatan yang berulang. Siklus ini menjadi ciri utama dalam penelitian tindakan kelas[8]. Penelitian tindakan kelas menurut Sanjaya merupakan upaya memecahkan masalah pembelajaran di dalam kelas melalui proses pengkajian masalah dan refleksi diri dengan melakukan berbagai tindakan yang terencana [4].

Jenis data dalam penelitian ini adalah data gabungan yakni data kuantitatif dan data kualitatif. Data kuantitatif adalah data yang berbentuk angka, sedangkan data kualitatif adalah data yang berupa kalimat atau gambar yang di peroleh dari observasi [9]. Pada penelitian ini data kuantitatif berupa nilai angka hasil peningkatan kemampuan berbicara anak kelompok A RA Bustanul Aulad Permata Biru Cileunyi Bandung, sedangkan data kualitatif berupa kondisi objektif sekolah serta kegiatan belajar mengajar yang dilakukan selama proses kegiatan belajar mengajar. Pengumpulan data yang digunakan pada penelitian ini melalui observasi, dokumentasi, dan unjuk kerja, selanjutnya teknik analisit data menggunakan rumus sebagi berikut: 


\section{Kemampuan Berbicara $=\frac{\text { Skor yang dicapai siswa }}{\text { skor maksimal }}$}

Setelah skor kemampuan berbicara setiap anak, kemudian dihitung nilai rataratanya melalui rumus sebagi berikut:

$X=\frac{\sum X}{N}$

Keterangan

$\mathrm{X} \quad$ : nilai rata-rata

$\sum \mathrm{X} \quad$ : jumlah nilai seluruh anak

$\mathrm{N} \quad$ : Jumlah anak

Setelah diperoleh skor kemampuan berbicara setiap anak dan nilai rataratanya secara keseluruhan melalui rumus diatas, kemudian hasilnya diinterprestasikan pada skala kualifikasi sebagai berikut:

Tabel 1. Interval dan Kategori Hasil Belajar

\begin{tabular}{ll}
\hline Interval & Predikat \\
\hline $80-100$ & Sangat Baik \\
\hline $70-79$ & Baik \\
\hline $60-69$ & Cukup \\
\hline $50-59$ & Kurang \\
\hline $0-49$ & Gagal \\
\hline
\end{tabular}

Tabel 2. Kualifikasi Penilaian

\begin{tabular}{llll}
\hline No & $\begin{array}{l}\text { Tingkat } \\
\text { Penguasaan }\end{array}$ & Kualifikasi & Keterangan \\
\hline 1 & $86-100$ & BSB & Berkembang Sangat Baik \\
\hline 2 & $71-85$ & BSH & Berkembang sesuai harapan \\
\hline 3 & $56-70$ & MB & Mulai Berkembang \\
\hline 4 & $\leq 55$ & BB & Belum Berkembang \\
\hline
\end{tabular}

Ketentuan

$(\mathrm{BSB})=$ Sangat Baik $(4)$

$(\mathrm{BSH})=$ Baik $(3)$

$(\mathrm{MB})=$ Cukup (2)

$(\mathrm{BB})=$ Kurang (1)

Penelitian ini bertempat di RA Bustanul Aulad komplek Permata Biru Blok X2 No 34 Desa Cimekar Kecamatan Cileunyi Kabupaten Bandung. Alasan peneliti untuk menentukan tempat penelitian ini karena peneliti menemukan masalah berupa kemampuan berbicara anak kelompok A di RA Bustanul Aulad belum berkembang 
secara optimal. Penelitian ini dilaksanakan pada semester ganjil tahun ajaran $2020 / 2021$.

\section{HASIL DAN PEMBAHASAN}

Kemampuan anak di kelompok A RA Bustanul Aulad Permata Biru Cileunyi Bandung sebelum diterapkannya metode bercakap-cakap atau disebut juga pada kegiatan pra-siklus menunjukkan bahwa kemampuan berbicara anak cenderung rendah. Berdasarkan analisis data hasil kemampuan anak sebelum menggunakan metode bercakap-cakap nilai rata-rata yang diperoleh 40.91 dari 7 anak. Hal ini menunjukkan bahwa kemampuan berbicara yang diperoleh dari hasil perhitungan data instrumen unjuk kerja masih dalam kategori gagal.dikarenakan pada saat pembelajaran guru lebih memfokuskan pada tugas lembar kerja siswa serta kurang memperhatikan aspek perkembangan anak sehingga guru lebih mendominasi pada saat pembelajaran berlangsung.

Faktor yang menyebabkan anak kurang interaktif pada saat pembelajaran berlangsung adalah kurangnya guru memberikan waktu dan kesempatan untuk anak mengungkapkan hal yang dirasakan oleh anak serta mengungkapkan jawaban dari pertanyaan yang disampaikan oleh guru dan masih adanya anak yang ditunggu oleh orang tua di dalam kelas yang menyebabkan kurang kondusifnya proses kegiatan belajar mengajar, faktor inilah yang menjadi penyebab rendahnya kemampuan berbicara anak di kelompok A RA Bustanul Aulad Permata Biru Cileunyi Bandung..

Menurut Suarca, dkk potensi kecerdasan bahasa yang dimiliki oleh anak tidak ada artinya apabila tidak dilatih, kemampuan berbicara anak usia dini merupakan salah satu potensi dari kecerdasan bahasa yang perlu di optimalkan[10]. Selanjutnya menurut Fanhas, mengemukakan bahwa metode bercakap-cakap bagi anak usia dini adalah salah satu metode yang efektif yang dapat digunakan untuk anak usia dini dalam proses pendidikan karena metode ini digunakan oleh Allah SWT dalam Al-Quran untuk memberikan pembelajaran kepada mahkluknya[5]. Salah satu metode meningkatkan kemampuan bahasa Anak Usia Dini yang tepat yaitu dengan mendengarkan musik (bernyanyi). "Bernyanyi adalah mengeluarkan suara dengan syair-syair yang dilagukan[11].

Berdasarkan uraian diatas perlu adanya perubahan metode belajar sesuai dengan kebutuhan dan perkembangan anak usia dini yaitu metode yang efektif digunakan untuk meningkatkan kemampuan berbicara anak usia dini dengan menggunakan metode bercakap-cakap.

Dilihat dari hasil observasi aktivitas guru pada proses pembelajaran dengan menggunakan metode bercakap-cakap pada siklus I masuk kedalam kategori cukup dengan nilai $65.62 \%$, sementara hasil observasi aktivitas guru selama pembelajaran menggunakan metode bercakap-cakap pada siklus II termasuk kedalam kategori sangat baik dengan perolehan nilai rata-rata sebesar 93.75\%.

Adanya peningkatan aktivitas guru tersebut disebabkan karena guru melakukan perbaikan pada setiap tahapan pembelajaran serta melalui tahapan-tahapan yang sesuai dengan teori pembelajaran menggunakan metode bercakap-cakap. Sriwahyuni, dkk 
mengemukakan bahwa seorang guru dituntut untuk bisa menggunakan metode pembelajaran yang sesuai dengan kebutuhan dan tahap perkembangan anak[12]. Metode pembelajaran berperan penting dalam mencapai keberhasilan tujuan pembelajaran serta implementasi strategi pembelajaran, karena suatu strategi pembelajaran hanya dapat diimplementasikan melalui penggunaan metode pembelajaran.

Selain itu, diperoleh hasil observasi aktivitas anak yang menunjukkan bahwa selama mengikuti kegiatan pembelajaran pada siklus I kemampuan berbicara anak masuk pada kategori kurang dengan perolehan nilai rata-rata sebesar 57.66\%, hal ini dikarenakan anak masih dalam kondisi adaptasi dengan lingkungan sekolah serta belum terbiasa dengan adanya pembejaran menggunakan metode bercakap-cakap. Sedangkan pada siklus II hasil observasi aktivitas anak termasuk pada kategori baik dengan perolehan nilai rata-rata sebesar $72.96 \%$, angka tersebut mengalami peningkatan dari angka sebelumnya karena guru memberikan motivasi dan arahan untuk anak mengikuti pembelajaran menggunakan metode bercakap-cakap.

Setiap anak memiliki karakteristik yang berbeda serta perkembangan dalam kemampuan berbicara juga dipengaruhi oleh beberapa faktor, tidak hanya di sekolah namun juga di lingkungan rumah serta lingkungan main anak seperti pendapat dari Hurlock faktor yang mempengaruh perkembangan bahasa anak adalah kesehatan, kecerdasan, keadaan sosial ekonomi, jenis kelamin, keinginan berkomunikasi, dorongan, ukuran keluarga, urutan kelahiran, metode pelatihan anak, kelahiran kembar, dan hubungan dengan teman sebaya[13].

Pendapat Hurlock diatas sesuai dengan penelitian ini, terdapat anak yang kurang mampu berbicara dipengaruhi oleh urutan kelahiran serta keinginan berkomunikasi yang berbeda. Anak yang cenderung aktif dan cerdas dalam mengungkapkan ide gagasannya juga dipengaruhi oleh kondisi ekonomi keluarganya.

Deskripsi Kemampuan Berbicara Anak Usia Dini di RA Bustanul Aulad Permata Biru Cileunyi Bandung Setelah diterapkannya Metode Bercakap-cakap setiap siklus Berdasarkan hasil analisis data perhitungan pada siklus I tindakan pertama diperoleh keterangan bahwa nilai rata-rata ketercapaian anak sebesar 47.08 dengan kategori kurang. Adapun banyaknya anak yang memiliki kemampuan berbicara di kelompok A RA bustanul Aulad Permata Biru Cileunyi Bandung dengan kategori penilaian dapat dilihat pada tabel berikut ini:

Tabel 3. Kemampuan Berbicara Anak Pada Siklus I Tindakan Pertama

\begin{tabular}{ccc}
$\begin{array}{c}\text { Ukuran Tingkat } \\
\text { Kemampuan Berbicara } \\
\text { Anak }\end{array}$ & $\begin{array}{c}\text { Jumlah } \\
\text { Anak }\end{array}$ & $\begin{array}{c}\text { Kriteria } \\
\text { Penilaian }\end{array}$ \\
\hline $80-100$ & - & Sangat Baik \\
\hline $70-79$ & - & Baik \\
\hline $60-69$ & - & Cukup \\
\hline $50-59$ & 3 & Kurang \\
\hline $0-49$ & 4 & Gagal \\
\hline Jumlah & $\mathbf{7}$ & \\
\hline
\end{tabular}


Dari data pada tabel diatas dapat dilihat bahwa kemampuan berbicara anak pada siklus I tindakan pertama terdapat 4 anak yang memiliki nilai dengan kategori gagal dengan rincian 1 anak memperoleh nilai 25, 1 anak memperoleh nilai 43.18, 1 anak memperoleh nilai 45.45, dan 1 anak memperoleh nilai 47.73. serta terdapat 3 anak yang memiliki nilai dengan kategori kurang dengan rician 1 anak memperoleh nilai 52.27, 1 anak memperoleh nilai 56.82 dan 1 anak memperoleh nilai 59.09.

Berdasarkan hasil analisis data perhitungan pada siklus I tindakan kedua diperoleh keterangan bahwa nilai rata-rata ketercapaian anak sebesar 55.19 dengan kategori kurang. Adapun banyaknya anak yang memiliki kemampuan berbicara di kelompok A RA bustanul Aulad Permata Biru Cileunyi Bandung dengan kategori penilaian dapat dilihat pada tabel berikut ini:

Tabel 4. Kemampuan Berbicara Anak Pada Siklus I Tindakan Kedua

\begin{tabular}{ccc}
\hline $\begin{array}{c}\text { Ukuran Tingkat } \\
\text { Kemampuan Berbicara } \\
\text { Anak }\end{array}$ & $\begin{array}{c}\text { Jumlah } \\
\text { Anak }\end{array}$ & $\begin{array}{c}\text { Kriteria } \\
\text { Penilaian }\end{array}$ \\
\hline $80-100$ & - & Sangat Baik \\
\hline $70-79$ & 1 & Baik \\
\hline $60-69$ & 2 & Cukup \\
\hline $50-59$ & 2 & Kurang \\
\hline $0-49$ & 2 & Gagal \\
\hline Jumlah & $\mathbf{7}$ & \\
\hline
\end{tabular}

Dari data pada tabel diatas dapat dilihat bahwa kemampuan berbicara anak pada siklus I tindakan kedua terdapat 2 anak yang memiliki nilai dengan kategori gagal dengan rincian 1 anak memperoleh nilai 27.27 dan 1 anak memperoleh nilai 47.73, terdapat 2 anak yang memiliki nilai dengan kategori kurang memperoleh nilai 56.82, terdapat 2 anak yang memiliki nilai dengan kategori cukup dengan rincian 1 anak memperoleh nilai 61.36 dan 1 anak memperoleh nilai 65.91, serta terdapat 1 anak yang memiliki nilai dengan kategori baik dengan memperoleh nilai 70.45.

Berdasarkan data diatas diperoleh informasi bahwa terdapat anak yang masih dalam kategori gagal, hal ini disebabkan anak masih adaptasi dengan lingkungan sekolah serta masih adanya anak yang ditunggu oleh orang tua sehingga kondisi pembelajar belum kondusif secara optimal. Sedangkan anak yang memperoleh nilai dengan kategori baik salah satu penyebannya di pengaruhi dengan kondisi anak yang sudah mampu beradaptasi dengan lingkungan sekolah serta merasa nyaman ketika mengikuti mempelajaran sehingga apa yang disampaikan oleh guru dapat diikuti dengan baik. Oleh karena itu, peneliti dan guru kolaborator menyimpulkan untuk merencanakan kembali untuk melaksanakan siklus II.

Berdasarkan hasil analisis data perhitungan pada siklus II tindakan pertama diperoleh keterangan bahwa nilai rata-rata ketercapaian anak sebesar 54.87 dengan kategori kurang. Adapun banyaknya anak yang memiliki kemampuan berbicara di 
kelompok A RA bustanul Aulad Permata Biru Cileunyi Bandung dengan kategori penilaian dapat dilihat pada tabel berikut ini:

Tabel 5.Kemampuan Berbicara Anak Pada Siklus Ii Tindakan Pertama

\begin{tabular}{ccc}
\hline $\begin{array}{c}\text { Ukuran Tingkat } \\
\text { Kemampuan Berbicara } \\
\text { Anak }\end{array}$ & $\begin{array}{c}\text { Jumlah } \\
\text { Anak }\end{array}$ & $\begin{array}{c}\text { Kriteria } \\
\text { Penilaian }\end{array}$ \\
\hline $80-100$ & - & Sangat Baik \\
\hline $70-79$ & 2 & Baik \\
\hline $60-69$ & 2 & Cukup \\
\hline $50-59$ & 2 & Kurang \\
\hline $0-49$ & 1 & Gagal \\
\hline Jumlah & 7 & \\
\hline
\end{tabular}

Dari data pada tabel diatas dapat dilihat bahwa kemampuan berbicara anak pada siklus II tindakan pertama terdapat 1 anak yang memiliki nilai dengan kategori gagal dengan memperoleh nilai 0 hal ini disebabkan anak tidak hadir pada saat pembelajaran berlangsung, terdapat 2 anak yang memiliki nilai dengan kategori kurang dengan rincian 1 anak memperoleh nilai 50 dan 1 anak memperoleh nilai 59.09, terdapat 2 anak yang memiliki nilai dengan kategori cukup dengan memperoleh nilai 65.91, serta terdapat 2 anak yang memiliki nilai dengan kategori baik dengan rincian 1 anak memperoleh nilai 70.45 dan 1 anak memperoleh nilai 72.73.

Berdasarkan hasil analisis data perhitungan pada siklus II tindakan kedua diperoleh keterangan bahwa nilai rata-rata ketercapaian anak sebesar 70.62 dengan kategori baik. Adapun banyaknya anak yang memiliki kemampuan berbicara di kelompok A RA bustanul Aulad Permata Biru Cileunyi Bandung dengan kategori penilaian dapat dilihat pada tabel berikut ini:

Tabel 6. Kemampuan Berbicara Anak Pada Siklus Ii Tindakan Kedua

\begin{tabular}{ccc}
\hline $\begin{array}{c}\text { Ukuran Tingkat } \\
\text { Kemampuan Berbicara } \\
\text { Anak }\end{array}$ & $\begin{array}{c}\text { Jumlah } \\
\text { Anak }\end{array}$ & $\begin{array}{c}\text { Kriteria } \\
\text { Penilaian }\end{array}$ \\
\hline $80-100$ & 6 & Sangat Baik \\
\hline $70-79$ & - & Baik \\
\hline $60-69$ & - & Cukup \\
\hline $50-59$ & 1 & Kurang \\
\hline $0-49$ & - & Gagal \\
\hline Jumlah & $\mathbf{7}$ & \\
\hline
\end{tabular}

Dari data pada tabel diatas dapat dilihat bahwa kemampuan berbicara anak pada siklus II tindakan kedua terdapat 1 anak yang memiliki nilai dengan kategori kurang dengan memperoleh nilai 52.27 serta terdapat 6 anak yang memiliki nilai dengan kategori sangat baik dengan rincian 1 anak memperoleh nilai 79.54, 1 anak memperoleh 
nilai 88.64, 2 anak memperoleh nilai 93.16, 1 anak memperoleh nilai 97.73 dan 1 anak memperoleh nilai 100.

Berdasarkan data diatas diperoleh informasi bahwa terdapat peningkatan kemampuan berbicara anak hal ini disebabkan anak mampu beradaptasi dengan lingkungan sekolah serta dukungan orang tua yang sudah tidak menunggu anaknya didalam kelas sehingga kondisi pembelajaran dengan menggunakan metode bercakapcakap menjadi kondusif dan efektif. Metode bercakap-cakap dapat membantu meningkatakan kemampuan berbicara anak karena metode bercakap-cakap memiliki banyak kelebihan salah satunya anak diberi kesempatan untuk mengemukakan pendapatnya [14].

Sedangkan anak yang memperoleh nilai dengan kategori kurang salah satu penyebannya di pengaruhi dengan kondisi psikologis anak yang pernah mengalami trauma disebabkan paksaan untuk ditinggalkan oleh orang tuanya. Menurut Sunaryanto faktor-faktor yang mempengaruhi perkembangan bahasa anak salah satunya yakni faktir kesehatan kesehatan Kondisi psikologis yang dialami oleh anak tergolong pada kategori anak yang memiliki metode pelatihan kemampuan berbicara yang kurang tepat dengan usia dan tahapan perkembangan anak[15]. Hurlock mengungkapkan bahwa, faktor-faktor yang mempengaruhi perkembangan bahasa anak terdiri dari kesehatan, kecerdasan, keadaan sosial ekonomi, keinginan berkomunikasi, dorongan, ukuran keluarga, urutan kelahira, pola asuh, kelahiran kembar, hubungan dengan teman sebaya dan kepribadian[16].

\section{KESIMPULAN}

Kemampuan berbicara anak usia dini di kelompok A RA Bustanul Aulad Permata Biru Cileunyi Bandung sebelum diterapkan metode bercakap-cakap masih rendah, hal ini dibuktikan dengan nilai rata-rata hanya mencapai 40.91 dan termasuk ke dalam kriteria gagal. Proses penerapan metode bercakap-cakap dalam proses pembelajaran pada anak usia dini kelompok A RA Bustanul Aulad Permata Biru Cileunyi Bandung pada setiap siklus, dilihat dari aktivitas guru dan anak pada siklus I tindakan pertama dan kedua tingkat keterlaksanaan aktivitas guru meningkat dari $62.5 \%$ menjad $68.75 \%$. Sedangkan pada siklus II tindakan pertama dan tindakan kedua tingkat keterlaksanaan aktivitas guru meningkat dari $87.5 \%$ menjadi 100\%. Kemudiatan tingkat keterlaksanaan aktivitas anak pada siklus I tindakan pertama dan tindakan kedua meningkat dari 52.04\% menjadi63.27\%. Sedangkan tingkat ketercapaian aktivitas anak pada siklus II tindakan pertama dan kedua meningkat dari $62.24 \%$ menjadi $83.87 \%$ dari data tersebut terlihat peningkatan yang signifikan. Kemampuan berbicara anak usia dini di kelompok A RA Bustanul Aulad Permata Biru Cileunyi Bandung setelah diterapkannya metode bercaka-cakappada setiap siklus mengalami peningkatan pada siklus I ke siklus II. Siklus I nilai rata-rata yang didapatkan sebesar 51.14 dengan kategori kurang, kemudian untuk siklus II memperoleh nilai rata-rata sebesar 70.62 dengan kategori baik. 


\section{PENGHARGAAN}

Terima kasih penulis ucapkan kepada kepala sekolah dan guru RA Bustanul Aulad Permata Biru Cileunyi Bandung, terlibat dan membantu terlaksananya penelitian ini. Tidak lupa diucapan terima kasih kepada editor dan reviewer Jurnal Murhum yang sudah memberikan kesempatan sehingga jurnal bisa untuk dipublish/diterbitkan.

\section{REFERENSI}

[1] N. Widiastita and L. Anhusadar, "Bermain Playdough dalam Meningkatkan Kecerdasan Visual-Spasial Melalui Home Visit di Tengah Pandemi Covid-19," Murhum J. Pendidik. Anak Usia Dini, vol. 1, no. 2, pp. 50-63, 2020, doi: 10.37985/murhum.v1i2.17.

[2] L. Anhusadar, "Evaluasi Pelaksanaan Standar Produk Hasil Belajar pada Satuan Pendidikan Anak Usia Dini," Al-TA'DIB J. Kaji. Ilmu Kependidikan, vol. 13, no. 1, p. 34, Jun. 2020, doi: 10.31332/atdbwv13i1.1775.

[3] P. H. Pebriana, "Analisis kemampuan berbahasa dan penanaman moral pada anak usia dini melalui metode mendongeng," J. Obs. J. Pendidik. Anak Usia Dini, vol. 1, no. 2, pp. 139-147, 2017, doi: 10.31004/obsesi.v1i2.34.

[4] S. N. I. Isnaini, "Pelaksanaan metode bercakap-cakap dalam pengembangan keterampilan bicara anak kelompok B. 1 di RA Permata Belia Kalipancur Semarang tahun pelajaran 2017/2018," UIN Walisongo Semarang, 2019.

[5] E. F. F. Kh, "Metode Bercakap-Cakap Bagi Anak Usia Dini: METODE BERCAKAPCAKAP BAGI ANAK USIA DINI," Nat. J. Kaji. Penelit. Pendidik. dan Pembelajaran, vol. 1, no. 1, pp. 1-6, 2016.

[6] E. Muafiah, "Strategi pembelajaran multiple intelligences di TK/RA Ponorogo," ThufuLA J. Inov. Pendidik. Guru Raudhatul Athfal, vol. 4, no. 1, pp. 63-88, 2016.

[7] S. Suriati, S. Kuraedah, E. Erdiyanti, and L. O. Anhusadar, "Meningkatkan Keterampilan Motorik Halus Anak melalui Mencetak dengan Pelepah Pisang," J. Obs. J. Pendidik. Anak Usia Dini, vol. 4, no. 1, p. 211, 2019, doi: 10.31004/obsesi.v4i1.299.

[8] S. Arikunto, "Prosedur Penelitian," Jakarta: Jakarta: Rineka Cipta, 2013.

[9] S. Supardi and A. Suharsimi, "Penelitian Tindakan Kelas," Jakarta Bumi Aksara, 2009.

[10] K. Suarca, S. Soetjiningsih, and I. G. A. E. Ardjana, "Kecerdasan majemuk pada anak," Sari Pediatr., vol. 7, no. 2, pp. 85-92, 2016.

[11] L. Fertiliana Dea, A. Setiawan, and L. Asmiyati, "Upaya Meningkatkan Kemampuan Bahasa Anak Usia 4-5 Tahun Melalui Metode Bernyanyi Menggunakan Media Kartu Gambar," Murhum J. Pendidik. Anak Usia Dini, vol. 1, no. 1, pp. 53-64, Jul. 2020, doi: 10.37985/murhum.v1i1.6.

[12] N. Triando and I. Yeni, "PENGEMBANGAN MOTORIK KASAR ANAK DI TAMAN KANAK-KANAK NEGERI PEMBINA PAINAN," Millenn. J. Pendidik. dan Stud. Islam, vol. 1, no. 1, pp. 74-82, 2021, doi: 10.34556/millennial.v1i1.90.

[13] E. Hurlock, "Psikologi Perkembangan: Suatu Pendekatan Sepanjang Rentang Kehidupan Edisi Kelima," Jakarta: Erlangga, 2004.

[14] E. Zubaidah, "Perkembangan bahasa anak usia dini dan teknik pengembangan di sekolah," J. Cakrawala Pendidik., vol. 3, no. 3, 2004, doi: 10.21831/cp.v3i3.7600.

[15] M. Sunaryanto, "Upaya Meningkatkan Kemampuan Berbicara Anak Usia 5-6 Tahun Dengan Media Poster Di Tk Aba Wonotingal Poncosari Srandakan Bantul Yogyakarta," Pendidik. Guru PAUD S-1, 2015. 
[16] Joni, "Hubungan pola asuh orang tua terhadap perkembangan bahasa anak prasekolah," J. paud tambusai, vol. 1, no. 6, pp. 42-48, 2015, doi: https://doi.org/10.31004/obsesi.v1i1.54. 